\title{
THE ENGINEER AS A FACTOR IN MODERN PROGRESS.*
}

BY

\author{
ALEX. C. HUMPHREYS, M.E., Sc.D., LL.D., \\ President, Stevens Institute of Technology. \\ Member of the Institute.
}

IN speaking briefly to this topic which has been assigned to me I am not unmindful of the fact that I am speaking to the members of many societies the membership of which is made up of men of other professions than of my own-engineering.

I have no sympathy with the man who tries to prove that his profession is the profession with regard to service to mankind. But I do sympathize with the man who demands for his profession proper recognition in view of its responsibilities and the fidelity and thoroughness with which the members of the profession live up to their responsibilities.

I do not believe that there is a general appreciation of the engineer's part in the world's work; of how his activities permeate practically every branch of the daily round.

When we call attention to details we are able to show that the engineer puts his mark upon nearly everything material which enters into our life. Wherever we see developed power, machinery, manufactures of all kinds, instruments, apparatus-yes, and articles of food-the engineer's work or influence can be found.

This being the case-and I wish I had time to enlarge on this proposition-it means that the engineer has necessarily to accept a heavy responsibility to maintain and increase the efficiency of . the world's operations.

I hold that he must carry a heavy responsibility with regard to governmental problems, and particularly so in this country, which is to-day hysterically active in proposing and trying to solve a multitude of problems, the majority of them involving, directly or indirectly, the industrial questions which the engineer should be qualified to solve.

Let me refer to one line among many.

* Read at a joint meeting of the scientific and engineering societies of Philadelphia held Friday, May I5, 1914: 
The engineer should be authoritatively employed in the regulation of our public utilities through the public service commissions, as he is now employed in the management of these public utilities.

It is not an adequate defence for the engineer to say that he has not been called by the voters and their representatives to take a place on the commissions except as a subordinate or member of the staff. The engineer must do his full share to convince the public that this work of regulation and control must not be left to the lawyers, and particularly to the lawyer-politicians. I am not reflecting on the lawyers, but I hold that there is room on these commissions for the engineer, the lawyer, the business man, and the members of all the professions, provided the individuals have good common-sense, common honesty, broad education, including practical experience in administration.

I certainly do not claim that an engineer is qualified to serve acceptably on one of these commissions only because he is an engineer. This applies equally, and perhaps more so, to the lawyer and others.

Judge Prouty, formerly chairman of the Interstate Commerce Commission and now head of the U. S. Board to value the railroads, has recently delivered a strong statement to the effect that, while he did not think so in the past, his experience leads him now to think that the engineer is better qualified temperamentally and by training to serve acceptably on these public service commissions than is the lawyer. To show that the engineers must assert themselves in this connection let me say by way of illustration that only to-day I heard the head of one of our greatest universities (a broad-minded and well-equipped man) state that it is generally understood and accepted that the engineer is not qualified to serve in such administrative positions, but his abilities have to be employed in subordinate and advisory capacities.

Unfortunately engineers have themselves given occasion for this opinion through their failure not infrequently to accept responsibility for the business, economic, and administrative features of the problems put before them. Also, the engineers who have been appointed to such positions have sometimes been the incompetents looking for a job. The engineer to place in such a position of grave responsibility should be a man who has made good-a man of constructive criticism, not of destructive criticism. 
We of the United States to-day are suffering from the destructive criticism of those who are incompetent to improve the conditions at which they are so ready to rail and to the reform of which they are willing to devote themselves at so much per hour, week, month, or year.

I am sorry to say that I am convinced (for I am not speaking hastily or rashly) that the college man, the professional men of the country, and especially the economists, are particularly to blame for our present conditions-conditions which I fear are to be worse before they are better.

The so-called educated men-meaning the man of school, college, and books-is to blame far more than the less-favored man if he by his ill-considered words leads others astray.

Particularly is this true of the teacher and professor. The State of Wisconsin has been particularly active in reform movements. Undoubtedly not a little good has been accomplished. But under the academic influence of the State University mistakes have been made.

We now read of organized protests by citizens in various parts of the State against the paternal policies of late so much in evidence in that State. This protest is not directed against public service commissions alone.

I quote from resolutions passed at the organization of the Taxpayers' League of Grant County: "We realize that good may be done in certain lines by commissions of experienced men properly restricted in their powers, but we condemn the useless multiplication of commissions to supervise and control every public and private act at the expense of the taxpayers of the State; we condemn the great increase in the cost of commission administration and the employment of hordes of useless employees at public expense. . . . The present conditions in the State of Wisconsin require immediate action for the protection of its people in their rights and property."

Things specified in the protest are: "The great mass of freak and useless legislation"; multiplication of laws; long and expensive legislative sessions; " tremendous indebtedness, and handling of State government by professional politicians."

At the bottom of these protests, bearing every evidence of sincere and honest indignation, lie the growing tax burdens, which in Wisconsin, as elsewhere, are pressing upon the people 
as never before in this country during times free from war and its immediate effects.

So long as public utilities and other industries are in private hands responsibility is definitely lodged and those accountable for their activities can be reached and held responsible. When the government assumes the functions of proprietorship, the whole relation to the public changes: transactions of all kinds are confused in the record, and the administration develops into the mysterious fetters of officialdom.

In the same paper from which I have abstracted these statements appears an article by President Van Hise, of the Wisconsin University. Certainly President Van Hise cannot be accused of reactionary tendencies. In fact, he has given evidence of being in sympathy with Wisconsin academic radicalism.

In this article Dr. Van Hise calls for a halt. Particularly he declares against the discrimination against "big business" so much in evidence to-day when the farmers are given freedom to be as big as they please in their combinations. This Van Hise calls a "profoundly immoral situation."

I confess that to get such a warning note from the president of the University of Wisconsin is about as encouraging as anything I have heard of late. Now I am ready for other pleasant surprises.

The legislators are now busy in Washington forging additional fetters for big business, which, properly managed and directed, operates for economy and efficiency.

In this connection let us remember that only a few years ago the States of the Union were almost without exception eagerly competing with each other in offering inducements to corporations to come in and do "big business"; now they are competing with the National Government to sandbag the unhappy victims of their previous legislative activities. Mistakes were made in the past, but if " big business" is to be killed, in fairness the politicians who cultivated and prospered through "big business" should be put out of the way also.

Now why do I say all this to this assemblage? One reason is that it is an unusual opportunity to speak to college men of many professions, and this is the day of college men, engineers and those of other professions, to serve their country, provided 
they do not assume, as too many college men do, that the college man is all-sufficient in the working-out of reforms.

I do not think I can do better than conclude by reading an editorial from the New York Times of yesterday.

" COLlegians AND CIVICS.

"In his little address to the Conference on Universities and their Relation to Public Service Mayor Mitchell brought out one point that may well be considered carefully by those responsible for the universities. By some of them, indeed, the study of it should be accompanied by fasting and prayer. He reported that in many cases that had come under his observation college men who had entered the public service temporarily, or with the intention to remain, were lacking in the ability, to handle their work practically, getting on with it less satisfactorily than young men with fewer and poorer 'advantages' than they. One of the objects which he held out for the consideration of the conference was coöperation to enable men who are in attendance at universities to get a practical knowledge of the workings of government that will fit them to take part in it when they enter business life.

"The suggestion is a pregnant one. In a lamentable degree it is true of the college teaching of civics that the practical side is neglected and undue stress is laid upon the theoretic side. This is not only true, but it is equally so that the theoretic side has too much to do with more or less abstract views as to the reforms that are assumed to be imperative in the organization of our public life. These views relate for the most part to what is called, in the vernacular, not to say the slang, of modern civics the 'uplift' of society with especial regard to social changes. This pabulum is exceedingly stimulating to young minds, and it is by no means without nutritive value properly administered; but it needs, in order to be safe, to be accompanied by a substantial element of practical instruction. For one thing, it is highly expedient that students who are to be trained to reform existing institutions and methods should have an accurate and as nearly complete knowledge of what they are to try to reform as possible.

"If we are to correct evils we must know as nearly as we can the nature and cause of these evils. This means that in training young men and young women in civics we should keep them as close as may be to concrete facts, and restrain them from arriving 
too soon at general principles and adopting tempting theories which are usually dangerous in the ratio that they are promising. These restraints are needed first by the minds of the young in their own interest, and, second, in the interest of the public. There is a distinct and peculiar risk in permitting, still more in inducing, the young to think that they have a mission for the bettering of the world before they have attained a knowledge of the world. That conception tends strongly to make them conceited, to transfer to their own credit the goodness of their intentions and to blind them to the truth about themselves and those with whom they have to deal. It puts into their minds much that has afterward to be got out by the stern processes of experience, which are often rude and cruel. In the meantime the public which these young enthusiasts are taught to believe they are serving loses a lot of good hard work which might be done if teaching were more properly adjusted to conditions.

Are we then to abandon the instruction in civics in our universities and banish therefrom the discussion of needed reforms? Certainly not. We must, however, recognize the extreme risks in theoretic teaching unless linked with thorough instruction in the concrete. That is more than a corrective or safeguard against erratic speculation. It is a positive preparation for the world of life, and a discipline in the tasks that await the student. Nor is the process a difficult one. It can be aided by the conference that Mayor Mitchell welcomed to the city and is, we understand, a part of its program. The results may well be beneficial to all concerned, for it is in the field of the concrete that the universities, such as that of Wisconsin, have accomplished most. It is a constantly widening field and may well occupy energies that in the past have been too much devoted to the theoretic."

From a long and instructive experience I say Amen! and Amen! to every word of this editorial.

Splitting of Tiles by Frost. C. RAD. (Tonind. Zeit., xxxviii, 649.) - Glazed tiles with strongly porous edges are split by frost, whereas unglazed tiles made of the same clay are not affected. Glazed bricks are more resistant than glazed tiles. This is due to the greater thickness and less exposed situation of the bricks, through which less water is absorbed, whereas thin, flat roofing tiles become fully saturated. 